\title{
Research in Language Education in South Africa: Problems \& Prospects
}

\author{
TV Manyike \\ Professor, College of Education, University of South Africa \\ manyitv@unisa.ac.za \\ EM Lemmer \\ Professor, College of Education, University of South Africa \\ Lemmeem@unisa.ac.za
}

\section{Doi:10.5901/mjss.2014.v5n8p251}

\section{Abstract}

\begin{abstract}
Language in education plays a key role in effective teaching and learning worldwide and learner proficiency in medium of instruction largely determines academic success. Sound research in language in education is crucial to inform language policy and practice which promotes social justice and learning for all. This is pertinent to South Africa, a linguistically diverse country whose history of language in education has been shaped by political interests as well as pedagogical considerations. This paper presents a review of key research in language in education conducted in South Africa over the last four decades with a view to distinguishing trends. The first section deals with major research in language education conducted during the apartheid period. The latter was characterised by a turbulent socio-political landscape and pressing educational dilemmas created by the apartheid government which enforced English (and, in certain instances, Afrikaans) as medium instruction in black education in a racially segregated and unequal schooling system. The second section concerns critiques of the implementation of transformative language policy and legislation introduced post-1994 and designed to promote multilingualism in a unitary desegregated schooling system. The final section highlights four large-scale research projects designed to assess postapartheid language in education practice in South African schooling. It is concluded that forty years of research in language in education shows little variance in the challenges that affect learners and teachers in South African schools despite sweeping changes in language in education policy. Recommendations are suggested that could improve practice.
\end{abstract}

Keywords: Language in education, policy, teaching and learning, research, South Africa

\section{Introduction}

Language in education plays a key role in effective teaching and learning worldwide. Learner and teacher proficiency in the medium of instruction largely determines academic success (Cummins 2012). The widespread choice of English as medium of instruction in multilingual education systems and its often deleterious impact on the academic achievement of English second language (ESL) learners in linguistically diverse schools emphasises the crucial importance of research in language in education with a view to informing language policy and practice which promotes social justice and learning for all (Hinkel 2011).

South Africa is a linguistically diverse country whose history of language policy and practice in education has been shaped, at times violently, by ideological and political interests rather than pedagogical considerations. Since the $19^{\text {th }}$ century English became the language of aspiration, national unity and liberation among black South Africans in spite of its role in colonial conquest (Alexander 2005). The status of English has strengthened in post-apartheid South Africa and has become the language of higher education, commerce and government as well as the preferred medium of instruction (referred to in post-1994 policy documents as the language of teaching and learning [LoLT]) in public schools (Lemmer 2010). Yet a major obstacle to ensuring equity education in the country has been the continued failure of the schooling system to meet the needs of black learners who are learning English as an additional language and using it as medium for the mastery of all other learning areas. Underachievement among black learners in South Africa is demonstrated annually in national school-leaving examinations (Postma \& Postma 2011) and annual literacy and numeracy assessments carried out nationally (Department of Basic Education [DBE] 2012a) or as part of international benchmarking assessments (Progress in International Reading Literacy Study (PIRLS) 2006; 2011) have been attributed to language related difficulties.

Against this background this paper presents a selective overview of research in language in education conducted 
in South Africa over more than 40 years with a view to distinguishing trends to inform language in education policy and practice. The first section deals with key research in language education conducted during the apartheid period. The latter was characterised by a turbulent socio-political landscape and pressing educational dilemmas created by the apartheid government which enforced English (and, in certain instances, Afrikaans) as a medium instruction in black education in a racially segregated and unequal schooling system. The second section concerns critiques of the implementation of transformative language policy and legislation introduced post-1994 designed to promote multilingualism in a unitary desegregated schooling system. The final section highlights the findings of four large-scale research projects designed to assess post-apartheid language and literacy practice in South African schooling. Based on this discussion conclusions about the current situation are drawn and brief recommendations made.

\section{Language in Education Research: The Apartheid Era}

During the apartheid era (1948-1994) the state upheld a centrally designed policy of bilingualism which gave status to only English and Afrikaans as official languages. The policy effectively ignored the needs of speakers of African and other languages and was aligned to the interests of white English and Afrikaans speakers. The medium of instruction in schooling for black learners was part of a highly politicised and frequently changing language in education policy. This policy made home language (HL) instruction compulsory during the first four years of schooling and stipulated that English and Afrikaans be taught as subjects from the first year of schooling, thus compelling children to become trilingual. By the 1970s English and Afrikaans were both used as media of instruction on a 50/50 basis while HL was used only for non-examination subjects thus lowering its status and its perceived usefulness in learning (Lemmer 2010). This untenable situation contributed to the watershed Soweto riots in 1976 and consequently schooling (together with language in education policy) played a key role in the ensuing liberation struggle in South Africa. Clearly research into language in education was urgently needed to find socio-political as well as pedagogical solutions. Early research, which focused on the plight of black learners' language development, was conducted in late $60 \mathrm{~s}$ and $70 \mathrm{~s}$ at the height of the repressive language regime of the apartheid government by LW Lanham, South Africa's first Chair of Linguistics at the University of the Witwatersrand (University of Witwatersrand 1998). Lanham, an eminent scholar of African languages as well as of English, was requested by KB Hartshorne (1992) of the Department of Bantu Education to investigate the issues associated with English as medium instruction in black education in Soweto township outside Johannesburg in the late 60s. Lanham's (1970) mandate was to design a research-based programme to strengthen the English language proficiency skills of black primary school teachers to improve the implementation of English as a medium of instruction. The project sample of four schools consisted of 18 primary school teachers and principals from Soweto as well as six inspectors. Lanham was assisted by Tony Traill, a linguist in African languages. His relationship with Hartshorn gave academic staff in his department access to school teachers in Soweto where they could conduct research into language problems experienced by black children. Lanham designed an inservice teacher training course which was attended by teachers, principals and school inspectors. The main aim of this first research phase was to give teachers an understanding of the systems of English pronunciation and English spelling and the link between pronunciation and spelling. A modified phonemic orthography as well as the skills of using a tape recorder as a teaching aid was taught. The second stage of the experiment came from the sample of teachers who wanted to teach children to read in English using the phonetic spelling or pronunciation spelling. The experiment was a success as children's reading skills in the four experimental schools improved more than those children in schools, which used the Look and Say method; as a result the programme was extended to 48 other schools. In a separate study Lanham (in Molteno Project 2000) conducted a study with teacher education institution to test black student teachers language proficiency skills. The findings of a study in which an English oral proficiency skills test was administered to six teacher education institutions for black teachers indicated that most respondents lacked basic vocabulary and could not grasp the meaning of simple questions, such as 'Where do you live'? Further research by Lanham, assisted by Miriam Dakile, a primary school principal in Soweto indicated traces of semi-lingualism among black primary school learners: learners failed to learn to read in English and failed equally to learn to read in HL (The Molteno Project 2000). Lanham's expertise was identified by the founders of the Molteno Project, a non-governmental initiative, and he played a key role in the establishment of the Molteno Institute for Language and Literacy (MILL), a non-governmental organisation, in 1974 with the goal of addressing black learners and teachers' literacy across the curriculum. Lanham's research together with the endeavours of the Molteno Institute demonstrated that black learners were not ready to switch to English as a medium of instruction after the fourth year of schooling; the linguistic environment encountered by black learners in the school and the home were mismatched; and that black teachers lacked the specialised knowledge of theories and methodologies required for effective $\mathrm{HL}$ and second language learning (Kingwill 1998). Lanham's work provided the foundation for literacy materials for black primary school 
children through the Breakthrough to Literacy and Bridge to Literacy programmes (University of the Witwatersrand 1998), which are used nationally and in eight other southern African countries. Nearly forty years later the Molteno Project, which had its genesis amidst the harsh linguistic injustices of the apartheid era, remains a 'household' name among language researchers and practitioners in South Africa. The success of its programmes lies in its rootedness in evidence-based research conducted by the organisation, external agencies and individuals who continually assess programme implementation locally and elsewhere (Molteno Institute for Language and Literacy n.d.).

A second influential research project into language in education policy and practice was launched in the mid-80s. The Threshold Project (I and II), undertaken by the Institute into Research into Language and the Arts (IRLA) of the Human Sciences Research Council (HSRC) under the leadership of CA Macdonald commenced in 1985. This comprehensive project included language testing, cognitive developmental research, materials development and classroom practices in black primary schools. The findings and recommendations of Threshold 1 comprised five reports (Macdonald 1990a; 1990b; 1990c; 1990d; Van Rooyen 1990) and a main consolidated report (Macdonald 1990). The consolidated report of Threshold 2 (Macdonald 1993) was aimed at disseminating the findings of Threshold 1. As was the focus with the seminal Molteno research, the overarching problem addressed was the language and related learning difficulties experienced by Standard Three (Grade 5) black children when they switched from HL to English as medium of instruction at the beginning of the fifth year of schooling. A central finding was that black learners were inadequately prepared for the sudden transition to English as the medium of instruction for the ten content subjects introduced in the fifth year of schooling. Black learners had had insufficient exposure to English and lacked the vocabulary necessary to cope with content instruction (Macdonald 1990; 1993). Macdonald (1990; 1993) argued that prior HL literacy was an essential condition for a successful bilingual language in education policy: if black learners were to use English as medium of instruction at higher levels of school, they first required sufficient opportunities to develop HL so that they could accomplish cognitively demanding tasks in it. Furthermore, basic commodities, such as sound nutrition and access to books and appropriate academic and community support for English learning, that is, language teaching as well as exposure to informal and authentic English language contexts, were needed. However, Macdonald (1990) did not ignore the reality of the prevailing parental preference among black families for English as medium of instruction. The project (Macdonald 1990; 1993) concluded with a recommendation for a modification of the 'straight for English' approach. However, it was acknowledged that the implementation of the transitional model was dependent on English-proficient teachers, particularly in the primary grades, expertise that was lacking in schools for black learners.

The Threshold Project has been evaluated as one of the most cardinal yet underrated research endeavours in the compendium of language in research in South Africa (Heugh 2002). Its findings and recommendations are still applicable to language practice in the South African education system and implementation of some kind of transitional model remains a conundrum for teachers given linguistic complexities of South African schooling in township and rural areas. In hindsight, what makes the Project particularly remarkable is its historical location: the basic research was undertaken from 1985-1988 when black schools were the arena of the violent struggle between black liberationists and the apartheid authorities. Herein language in education was both the key grievance held by the disenfranchised black population and a highly sensitive political issue confronting the beleaguered apartheid regime. Threshold projects 1 and 2 were influential in the compilation of the National Educational Policy Initiative (NEPI), a precursor to initial post-apartheid education policy and influenced legislation around medium of instruction in the last years of the apartheid era (Macdonald 1993).

\section{Moving on: Critiques of Post-Apartheid Language in Education Policy}

After 1994 the new government launched incisive endeavours to shape language in education policy. The South African Constitution (RSA 1996a) lent all eleven South African languages equal status (Sepedi, Sesotho, Setswana, Siswati, Tshivenda, Xitsonga, Afrikaans, English, isiNdebele, isiXhosa and isiZulu); the South African Schools Act (1996b) made language policy in schools a function of the School Governing Body; the Language in Education Policy (LiEP) (DoE 1997) promoted additive bilingualism through $\mathrm{HL}$ education (primarily in the early years) and gradual access to additional languages, including, of course, English. The Revised National Curriculum Statement (DoE 2002) clarified the LiEP by stipulating that all learners should study their $\mathrm{HL}$ and at least one additional language as language subjects from Grade 1 and should complete the study of an African language for a minimum of three years by the end of the 12th year of schooling. This has been reaffirmed by the Curriculum and Assessment Policy Statements (CAPS) (DBE 2012b). Thus, all South African learners have the right to be educated in the official language(s) of their choice in public education institutions. However, this right is limited by the state's ability to provide for this right only in a context where "that education is reasonably practicable" (Section 29(2), RSA 1996a). These developments embody the transformation of the former state language policy of bilingualism linked to race to a language policy environment that promotes linguistic 
pluralism (Webb 1999). To support policy, language planning agencies and policy implementation institutions were established, among others, the Pan South African Language Board (PANSALB), an independent statutory body, which has the mandate to advise central and provincial government on all matters pertaining to language policy and language use and the National Language Service (NLS) tasked mainly with translation (Alexander 2003). Furthermore, the desegregation of formerly whites-only schools created a new linguistically diverse environment in which the goals of multilingualism could, at least in theory, be realised in innovative ways (Meier, Lemmer \& van Wyk 2012). Together these statutory developments constitute one of the world's most progressive language in education policies aimed at multilingualism whereby the African languages are acknowledged as vehicles of educational delivery (Probyn, Murray, Botha, Botya, Brooks \& Westphal 2002).

In practice, however, effective implementation of this language in education policy has not been realised as intended. In the post-apartheid period most public schools attended by black learners continue to follow the practice entrenched during the apartheid era: primary school learners switch from HL to English as LoLT for all learning areas at the onset of Grade 5 (the fifth year of schooling) (DBE 2010) in the absence of a definitive solution to the question of the most beneficial timing and management of the transition from L1 to English (Murray 2012). In spite of rhetoric which supports the maintenance of African languages and pedagogical arguments to the same end, the overriding parental choice is for black children to be educated in English as early as possible due to the perceived socio-economic advantages associated with English proficiency (DBE 2010). In a considerable number of individual cases black learners may be immersed in English medium preschools or in Grade 1 as a result of school choice. Many black parents view HL instruction and maintenance as unnecessary (Ridge 2006; Webb 2006). The black elite and middle class prefer to enrol their children in independent or in public schools which formerly catered for whites only (the so-called ex-model $\mathrm{C}$ schools) where English language learning is supported by rich material resources and a qualified, English-proficient teaching corps. In contrast, black children from low socio-economic backgrounds who make up $80 \%$ of the entire school population attend township, rural or inner city schools which lack infrastructure, resource materials and teachers who are proficient in English (Fleisch 2007). Thus, school type has become a determinant of a child's educational success and life outcomes (Lemmer \& Manyike 2012).

Against this background, post-apartheid language policy analysts, Neville Alexander and Kathleen Heugh have criticised the state's lack of political will to implement multilingual policy and legislation (DBE 2011; Heugh \& Prinsloo 2013). Language activist, Neville Alexander (1936-2012), a former political prisoner together with Nelson Mandela during the apartheid period, long highlighted the ideological and political objectives of language planning and proposed an alternative language policy for a democratic South Africa in the late 80s (Alexander 1989). Alexander (2000; 2002; 2003; 2005) proposed that although language policies are popularly considered to be a set of protocols created by language 'experts', they are context-specific and shaped by often unstated underlying ideological and political goals and political, social, economic, cultural and legal frameworks. Post-1994 Alexander (2007) argued that political change and ensuing legislation supporting multilingualism had not essentially transformed sentiment to language in education and in broader society. In post-apartheid South Africa, the hegemony of English and the marginalisation of the African languages was reinforced rather than challenged. Black people had actively embraced English at the expense of the African languages as an expression of defiance against apartheid and of rejection of Afrikaans as the language of the oppressors. Consequently, blacks had and continued to mistrust the value of $\mathrm{HL}$ education which they associated with tenets of Bantu Education (Alexander 2007). Alexander (2004) argued that most blacks suffer from what Ngungi wa Tiyonga called the "colonised mind in that they do not believe that African languages can or should be used for higher-order functions although they cherish them and are committed to their maintenance in the primary spheres of the family, the community and for religious purposes. After nearly fifteen years of education transformation in South African schools, Alexander (DBE 2011) continued to call for a move from an English medium to a HL based education system. He maintained that English as the First Additional Language should be introduced systematically so that learners could, if necessary, gradually transfer skills from the $\mathrm{HL}$ to English. He advocated the use of $\mathrm{HL}$ as medium of instruction (or LoLT) as long as possible and that $\mathrm{HL}$ should in any case be taught as a subject throughout the schooling of the learner.

Similarly, Heugh $(1993 ; 1995)$ readily commended the post-apartheid language policy which accorded equal status to the country's eleven languages as among the best in the world but pointed out that without an effective government strategy to rehabilitate the African languages, they will continue occupy to a poor second place against English. Early in the post-apartheid period Heugh $(1999 ; 2000)$ critiqued the disappointing lack of implementation of a multilingual language in education policy in schooling and the ongoing demise of the African languages as viable media for education delivery. She (1999; 2002) contested established propositions held about language in education practice in South Africa by identifying five 'myths' concerning language practice in schooling: the myth of the paucity of local research to inform language in education; the myth that English is the only suitable means to deliver quality education to the exclusion of the 
African languages; the myth that black children are multilingual and therefore do not need HL education; and the myth that bilingual or multilingual education which includes full acquisition of $\mathrm{HL}$ is too expensive. Finally, she interrogated the widely held proposition that black parents desire 'a straight for English' approach, a proposition put forward in the Threshold Project (MacDonald 1990; 1993) albeit accompanied by recommendations to inform parents about needed modifications to a 'straight for English' approach. Like Alexander, Heugh ( Heugh \& Prinsloo 2013) has sustained her stance on the valuable role of the African languages and the need for transitional bilingualism in South African schools.

The outstanding feature of the work of these analysts is their unfaltering critique of language in education policy in a democratic South Africa where state commitment to a multilingual policy lacks teeth (Perry 2013). Both champion a language rights form of multilingualism in which the importance of $\mathrm{HL}$ is upheld alongside the need for an introduction of additional language(s) for all South Africans.

\section{Recent Assessment of Language in Education Practice}

Language in education issues during the twenty years following democratic change in South Africa has provided individual scholars fertile ground for research as borne out by published theses and dissertations (Sabinet 2014) and the contents of at least three journals dedicated to language research in southern Africa. Coverage of thereof falls outside of the scope of the selective review contained in this paper; instead attention is given to four large-scale projects into the state of language and literacy in South African schools.

The status of the language of learning and teaching (LoLT) in South African public schools: A quantitative overview (DoE 2010). The primary purpose of this report was to provide a trend analysis of language data for the period 1997/98 to 2007 based on the Department of Basic Education's school survey which gathers data from schools regarding: number of learners according to HL; number of learners using a particular LoLT by grade; and the number of learners enrolled for the first, second and third additional languages by schooling phase. Trend data revealed patterns and shifts in the status of the LoLT and additional languages in schools over time and these are a platform for assessing the effectiveness of policy implementation. Findings indicated an increase in the number of Foundation Phase children (Grade R-3) learning in their $\mathrm{HL}$ (80\% in 2007 versus 55\% in 1998). However, no corresponding improvement in learning outcomes was reported. Furthermore, by Intermediate Phase (Grade 4 onwards) the majority of children were learning in English as LoLT (and a far lesser percentage in Afrikaans). However, the majority of learners do not study English or Afrikaans as a subject (at either HL or additional language level) in the Foundation Phase, even though they learn via the medium of English or Afrikaans from Grade 4 onwards. This would imply that many learners would have had insufficient grounding in English (or Afrikaans) to cope with using it as LoLT from Grade 4 onwards. Moreover, $r$, there was a modest increase in the number of African language single medium schools since 1998. The recommendations of this report call for greater coherence between the LiEP (1997) and Revised National Curriculum Statement (DoE 2002); a clearer policy regarding the African languages; the production and dissemination of Foundation Phase teaching and learning material in all eleven languages; and the inclusion of language related issues in teacher training and development programmes. The absence of specific strategies in the recommendations designed to take steps to resolve problems indicated in the report are striking, particularly with regard to the development and extension of African languages as media of education delivery.

The Progress in International Reading Literacy Study (PIRLS) (Howie, Van Staden, Tshele, Dowse \& Zimmerman 2011) was a project in which 20000 South African learners participated and was conducted by the Centre for Evaluation and Assessment (CEA), University of Pretoria, under the auspices of the International Association for the Evaluation for Educational Achievement (IEA). The project focused on two purposes of reading: reading for literary experience; and reading to acquire and use information and assessed reading literacy at Grade 4 level in the eleven official languages and at Grade 5 level in Afrikaans or English. At both levels South African children achieved well below the International Centre Point. Learners tested in Afrikaans and English performed relatively well and above the international means; those tested in all African languages, despite the fact that most participants wrote the test in their $\mathrm{HL}$, achieved very low outcomes and learners tested in Sepedi and Tshivenda were especially low. Few South African learners (6\%) were able to read at an advanced level: $71 \%$ were able to reach a rudimentary level of reading and attain the Low International Benchmark. Factors contributing to poor performance which were identified included poor literacy resources in homes and schools and large classes. Interestingly, medium of instruction or LoLT was not singled out as contributory factor although poor performance in African languages indicated a failure to realise $\mathrm{HL}$ literacy.

The National Education Evaluation and Development Unit (NEEDU) (2013) undertook an inquiry into the State of Literacy Teaching and Learning in the Foundation Phase (Grades 1 and 2) based on a 2012 survey in high growth areas in all nine provinces of South Africa. The report confirmed the complex linguistic composition of Foundation Phase classrooms and the learning difficulties faced by large numbers of children who do not receive the first two years of 
schooling in their $\mathrm{HL}$ due to the mismatch between LoLT and $\mathrm{HL}$. The implication is that most learners in Grade R-3 do not acquire competency in the fundamental skills of reading, writing and mathematics due to language difficulties. An important contribution of this report is its analysis of the complexities of the $\mathrm{HL}$ and LoLT mismatch in African language medium classrooms ascribed to the dialectisation (the use of non-standard forms) of the African languages, including Afrikaans. This problematises the comprehension of written communication in standard form as found in textbooks used by learners as well as difficulties encountered by teachers with curriculum documents which they struggle to understand, albeit provided in all eleven languages. Terminology used in mathematics teaching is an additional problem: teachers preferred to use English to teach maths even where African language terminology exists. The report concluded that if education authorities are committed to $\mathrm{HL}$ instruction in the Foundation Phase, the African languages should be standardised and a full set of learning materials developed for the first three years of schooling. The Report confirmed that Foundation Phase learners continue to fail to achieve proficiency in English as additional language and are thus hindered in their access to learning content presented in the Intermediate Phase. Although the CAPS curriculum (DBE 2012b) first introduced in 2011 encourages additive bilingualism, this goal has not been reached in schools.

Finally, the report entitled The role of language and literacy in preparing South African learners for educational success: lessons learnt from a classroom study in Limpopo province (Heugh \& Prinsloo 2013) carried out under the auspices of the HSRC and based on ethnographic research of twenty primary school classrooms in the rural province of Limpopo also underlines the dilemma of language in education practice. The main finding indicates that learners' $\mathrm{HL}$ development is abandoned prematurely in the interests of a new additional language. Although the latter is not identified with English, other findings (DBE 2010; DBE 2013) strongly indicate that this is the case.

\section{Conclusion and Recommendations}

Forty years of research in language in education indicate little variance in the challenges that affect learners and teachers in South African schools. In spite of the large body of research evidence that demonstrates that learners learn best in $\mathrm{HL}$, conditions for $\mathrm{HL}$ literacy acquisition in primary schools remain dismal. The majority of learners whose $\mathrm{HL}$ is not the medium of instruction continue to experience academic underachievement as $\mathrm{HL}$ education is largely ignored by the education authorities in spite of rhetoric to the contrary. The results of this review show that the education system in South Africa has not changed much as the majority of black learners continue to experience similar challenges to those experienced 35 years ago. Most black schools remain overcrowded with inadequate language learning material and an under-qualified teaching corps particularly with regard to appropriate theories of second language acquisition. Despite one of the best language in education policies in the world, its effective implementation remains a pipe dream. Failure to teach learners in their HL rob them of their self-identity and alienate them from their culture as it is through HL teaching that learners are empowered both academically and culturally to become lifelong learners and productive members of society .

Based on this review brief recommendations are made for future language in education research and practice in South African schooling. African language departments in South African universities, which have suffered a demise since 1994 in spite of their wealth of expertise (Webb 2006), should be revitalised and the government should task these departments with the development of the literacy language materials for the Foundation Phase in the nine official African languages as has been called for on several fronts. Furthermore, research should be conducted into the development of indigenous African language teaching models, particularly with regard to the maintenance of $\mathrm{HL}$ and the introduction of additional languages, since the models used in this regard are imported from Western-based second language teaching models. Experienced African language teachers who are native speakers should be employed in previously white schools to teach at least one of these languages as additional language to all South African children irrespective of linguistic background. South Africa is a multilingual country and its prospects and global competitiveness depend not only on the twenty percent of learners who can compete globally with their peers but with the eighty percent of mostly black learners whose prospective outcomes and learning conditions are little different to what they were more than three decades ago. Although large scale research has been conducted in South Africa since 1994, these are not longitudinal studies and they are not as consolidated as the previous studies. For language in education research to have the desired impact, a link between school-based research, institutional support and teacher training is required. Large scale classroom-based research funded by government should be conducted by the universities, which house the teacher education colleges and departments of linguistics, English and the African languages in collaboration with language teachers in schools. Language education programmes informed by the research should be developed with the view to the professional development of students enrolled in initial teacher training and inservice teachers together with effective monitoring strategies to evaluate the efficacy of their implemented. 


\section{References}

Alexander, N. (1989). Language policy and national unity in South Africa/Azania. Cape Town: Buchu Books.

Alexander, N. (2000). English unassailable but unattainable: The dilemma of language policy in South African education. PRAESA Occasional papers no.3. Cape Town: PRAESA.

Alexander, N. (2002). Linguistic rights, language planning and democracy in post- apartheid South Africa. In Baker, C. (Ed.), Language policy lessons from global models (pp). Monterey, CA: Monterey Institute of International Studies.

Alexander, N. (2003). The African renaissance and the use of African languages in tertiary education. PRAESA Occasional Papers No 13. Cape Town: PRAESA.

Alexander, N. (2004). The politics of language planning in post-Apartheid South Africa. Language Problems and Language Planning, 28 (2), $113-130$.

Alexander, N. (2005). Key issues in language policy for southern Africa. In R. Trewby, \&S. Fitchat (Eds.), Language and development in southern Africa: Making the right choices. (pp.)Windhoek: Gamsberg Macmillan

Alexander, N. (2007). Affirmative action and the perpetuation of racial identities in post-apartheid South Africa. Transformation Critical Perspectives on Southern Africa 63 (1), 92 -108.

Alexander, N., \& Heugh, K. (1999). Language policy in the New South Africa. In A. Zegeye, \& R. Kriger, (Eds.), Cultural change and development in South Africa. Special Issue, 1998-9 Culturelink, 9-33.

Cummins, J., Mirza, R., \& Stille, S. (2012). English language learners in Canadian School: Emerging directions for school based policies. TESL Canadian Journal. 29 (6), 25 - 48.

Department of Basic Education (DBE). (2010). The status of the language of learning and teaching (LoLT) in South African public schools: A quantitative overview. Pretoria: Department of Basic Education.

Department of Basic Education (DBE) (2011). Report of the colloquium on language in the schooling system. Pretoria: Department of Basic Education.

Department of Basic Education (DBE) (2012a). Report on the annual national assessments 2012: Grades 1 to 6 and 9 . Pretoria: Department of Basic Education.

Department of Basic Education (2012b). Curriculum and assessment policy statements. Pretoria: Department of Basic Education.

Department of Education. (1997). Language in education policy, section 3(4)(m) of the National Education Policy Act, 1996 (Act 27 of 1996). Pretoria: RSA

Department of Education (2002). Revised national curriculum statement Grades R-9. Overview. Pretoria: RSA

Hartshorne, K. (1992). Crisis and challenge: Black education 1910-1990. Cape Town: Oxford University Press.

Heugh, K. (1993). The place of English in relation to other languages in South Africa. Per Linguam, 9(1), 2-10.

Heugh, K. (1995). Disabling and enabling: implications of language policy trends in South Africa. In Mesthrie, R (Ed.), language \& social history (pp.). Studies in South African Sociolinguistics. Cape Town: David Phillips.

Heugh, K. (1999). Languages, development and reconstructing education in South Africa. International Journal of Educational Development, 19, 301-313.

Heugh, K. (1999). The promise of multilingualism and education in South Africa: Mirage or reality? In Feral, C. (Ed.), Proceedings of the international seminar - Language and Education: Parameters for a Multicultural South Africa (pp.). December 1998, University of La Réunion. Alizés 18,64-82.

Heugh, K. (2000). Multilingual voices - isolation and the crumbling of bridges. Agenda, 46,21-33.

Heugh, K. (2002). The case against bilingual and multilingual education in South Africa: Laying bare the myths. Perspectives in Education, 20(1), 171-196.

Heugh, K. (2003). Can authoritarian separatism give way to language rights? Current Issues in Language Planning, 4(2), $126-145$.

Heugh, K. \& Prinsloo, C.H. (2013). The role of language and literacy in preparing South African learners for educational success: lessons learnt from a classroom study in Limpopo province. Pretoria: HSRC Press.

Fleisch, B. (2008). Primary education in crisis: why South African school children underachieve in reading and mathematics. Cape Town: Juta.

Hinkel, E. (2011). Handbook of research in second language teaching and learning. New York: Routledge.

Howie, S., Van Staden, S., Tshele, M., Dowse, C. \& Zimmerman, L. (2012). South African children's reading literacy achievement: Executive Summary. Pretoria: CEA, University of Pretoria.

Kingwill, P. (1998). Transforming language education in South Africa. A history of the Molteno Project, Braamfontein: Molteno.

Lanham, L.W. (1970). English teaching in South African schools. In Rose, B. (Ed.), Education in southern Africa. London: CollierMacmillan.

Department of Education. (1997). Language in education policy. [Online] Available: http://www.education.gov.za/Documents/policies /LanguageEducationPolicy1997.pdf [ 30 November 2010].

Lemmer, E.M. (2010). Language policy and linguistic realities in South African schooling. In Lemmer, E.M. \& Van Wyk, N. (Eds.), Themes in South African education. Johannesburg: Heinemann.

Lemmer, E.M. \& Manyike, T.V. (2012). Far from the city lights: English reading performance of ESL learners in different types of rural primary schools. Per Linguam, 28(1), 14-33.

Macdonald, C.A. (1990). Crossing the threshold into standard three in black education: The consolidated main report of the Threshold Project. Pretoria: HSRC Press. 
MacDonald, C.A. (1990a). How many years aave you got? English language skills evaluation. A Final Report of the Threshold Report. Pretoria: HSRC.

MacDonald, C.A. (1990b). Ball-point pens and braided hair: An analysis of reasoning skills and the curriculum. A Final Report of the Threshold Project. Pretoria: HSRC.

MacDonald, C.A. (1990c). Swimming pp the waterfall: A study of school-based learning experiences. A Final Report of the Threshold Project. Pretoria: HSRC.

MacDonald, C.A. (1990d). Standard three general science research 1987-8. A Final Report of the Threshold Project. Pretoria: HSRC.

Macdonald C.,A. (1993). Towards a new primary curriculum in South Africa. A Final Report of the Threshold II Project. Pretoria: HSRC.

Molteno Institute for Language and Literacy Undated. Articles, testimonials. [Online] Available: www.molteno.ac.za. [30 December 2013].

Molteno Project. (2000). Language, literacy and educational development. [Online] Available: www.molteno.ac.za. [30 December 2013].

Murray, S 2012. The challenges of designing a common, standards-based curriculum for all South Africa's languages. Per Linguam, 28(2):84-94.

National education evaluation \& development unit (NEEDU).( 2013). The state of literacy teaching and learning in the foundation phase. Johannesburg: NEEDU.

NEPI (1992). Language report of the NEPI Language Research Group. Cape Town:????

Perry, T. (2004). The case of the toothless watchdog: Language rights and ethnic mobilization in South Africa. Ethnicities, 4(4),501-521.

Postma, M. \& Postma, D. (2011). Who is laughing last in the South African classroom? A critical reflection on language in education. Southern African Linguistics and Applied Language Studies, 29(1),43-64.

Progress in International Reading Literacy Study (PIRLS) 2006; 2011

Probyn, M., Murray, S., Botha, L., Botya, P., Brooks, S.M. \& Westphal, V. (2002). Minding the gaps: an investigation into language policy and practice in four Eastern Cape districts. Perspectives in Education, 20 (1), 29- 47.

Republic of South Africa (RSA). (1996a). Constitution of the Republic of South Africa, Act No. 108 of 1996. Government Gazette vol 378, no 17678. Pretoria: President's office.

Republic of South Africa (RSA). (1996b). South African Schools Act, Act No. 84 of 1996. Government Gazette vol 377, no 17579. Cape Town: Office of the President (no 1867).

Ridge, S. (2006). Language policy in a democratic South Africa. In Harriman, M. \&Burnaby, B. (Eds.), Language policy in English dominant countries. Cleveland: Multilingual Matters.

Sabinet Reference. (2014). Theses and dissertations. [Online] Available: http://referenc.Sabient.co.za. [2 January 2014].

University of Witwatersrand. (1998). Obituary: Leonard Walter Lanham 1921-1997. African Studies 57(2): ix.

Van Rooyen, W. (1990). The disparity between English as a subject and English as the medium of learning. Pretoria: HSRC.

Webb, V. (1999). Multilingualism in a democratic society: The overestimation of the language policy. International Journal of Educational Development, 19 (4-5), 351-366.

Webb, V. (2006). Language policy development in South Africa. Centre of Research in the Politics of Language. University of Pretoria 